\title{
Grey-Turner's sign following iatrogenic duodenal perforation
}

\author{
Mark McKelvie, ${ }^{1,2}$ Michael Bath, ${ }^{2}$ James Max Wilde ${ }^{2}$
}

'University of Cambridge School of Clinical Medicine, Cambridge, UK

${ }^{2}$ Bedford Hospital NHS Trust, Bedford, UK

\section{Correspondence to}

Mark McKelvie,

markmckelvie@gmail.com

Accepted 17 May 2017
CrossMark

To cite: McKelvie M, Bath $M$, Wilde JM. BMJ Case Rep

Published Online First:

[please include Day Month

Year]. doi:10.1136/bcr-2017220648

\section{DESCRIPTION}

A 45 -year-old man presented with a 6-hour history of acute epigastric pain radiating to the back, following endoscopic retrograde cholangiopancreatography (ERCP), sphincterotomy and biliary stenting for obstructive jaundice secondary to choledocholithiasis.

The patient was markedly tender in the epigastrium and right flank, with the pain becoming progressively worse over the following 48 hours. A CT scan of the abdomen and pelvis was performed, revealing a normally enhancing pancreas with pockets of free air and fluid adjacent to the second part of the duodenum and in the retroperitoneum, extending to the right flank, an associated perinephric collection and extensive peritoneal fat stranding. Inflammatory markers were raised alongside a moderately elevated amylase, with a clotting screen within normal limits and stable serial haemoglobin levels. These findings were in keeping with a posterior duodenal perforation (figure $1 \mathrm{~A}, \mathrm{~B}$ ).

Four days post-ERCP, the patient reported discolouration on the right side of his abdomen. There was no history of trauma. On examination, there was a large area of erythema in the right flank, associated with pitting oedema of the subcutaneous tissues; no discrete mass was palpable (figure 2). Such an appearance was in keeping with the original description of Grey-Turner's sign.

The patient was treated conservatively with nasogastric tube decompression, intravenous antibiotics and acid suppression therapy. The patient made a good recovery, both clinically and biochemically, with a concurrent gradual reduction in the eponymous sign over the next few days. We believe this is the first described case of Grey-Turner's sign presenting following a duodenal perforation.

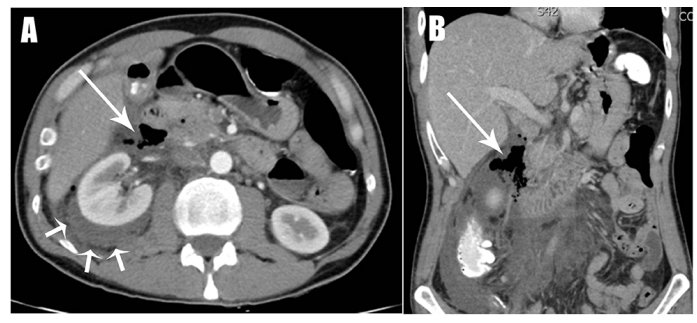

Figure 1 Axial (A) and coronal (B) CT images demonstrating the retroperitoneal collection containing gas and fluid in association with the second part of the duodenum (long arrows). There is an associated perinephric collection (short arrows).

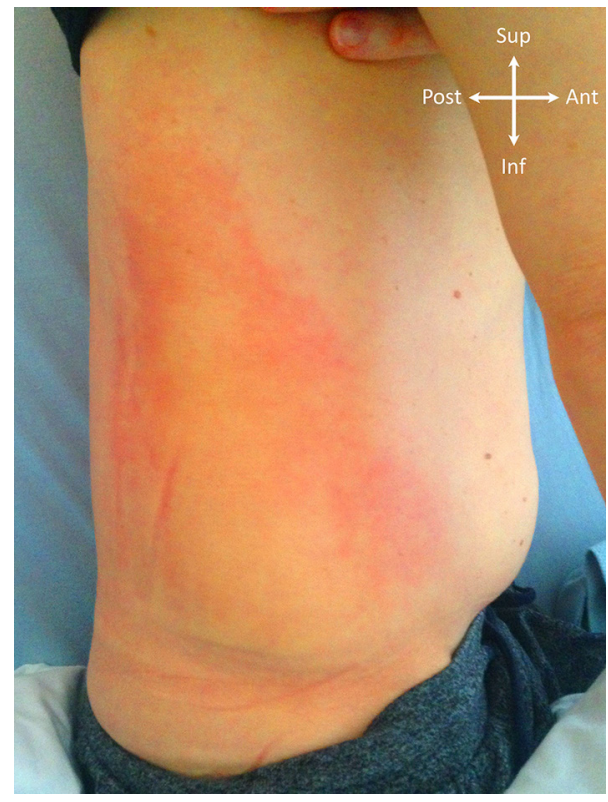

Figure 2 Erythematous discolouration and pitting oedema of the right flank (Grey-Turner's sign) manifesting 4 days after the onset of symptoms.

\section{Learning points}

- Consider perforation in individuals presenting with acute abdominal pain following $E R C P$, in addition to acute pancreatitis.

- Grey-Turner's sign is caused by tracking retroperitoneal inflammatory exudate and/ or blood, usually associated with acute pancreatitis.

Contributors MMK and MB: joint primary authors. Equal contribution towards the manuscript including conception of the work and drafting and revision of the article. JMW: critical revision of the article. All authors: final approval of the version to be published.

Competing interests None declared.

Patient consent Obtained.

Provenance and peer review Not commissioned; externally peer reviewed.

(C) BMJ Publishing Group Ltd (unless otherwise stated in the text of the article) 2017. All rights reserved. No commercial use is permitted unless otherwise expressly granted.

\section{REFERENCE}

1. Turner GG. Local discoloration of the abdominal wall as a sign of acute pancreatitis. Br J Surg 1919;7:394-5. 
Copyright 2017 BMJ Publishing Group. All rights reserved. For permission to reuse any of this content visit http://group.bmj.com/group/rights-licensing/permissions.

BMJ Case Report Fellows may re-use this article for personal use and teaching without any further permission.

Become a Fellow of BMJ Case Reports today and you can:

- Submit as many cases as you like

- Enjoy fast sympathetic peer review and rapid publication of accepted articles

Access all the published articles

- Re-use any of the published material for personal use and teaching without further permission

For information on Institutional Fellowships contact consortiasales@bmjgroup.com

Visit casereports.bmj.com for more articles like this and to become a Fellow 